\title{
Satisfaction levels with family physician services: a pilot national health programme in the Islamic Republic of Iran
}

Mohammad Fararouie, ${ }_{1}^{1}$ Mehdi Nejat, ${ }^{2}$ Humidreza R. Tabatabaie, ${ }^{3}$ Parvin A. Kazerooni ${ }^{1}$ and Mehdi Akbarpoor ${ }^{4}$

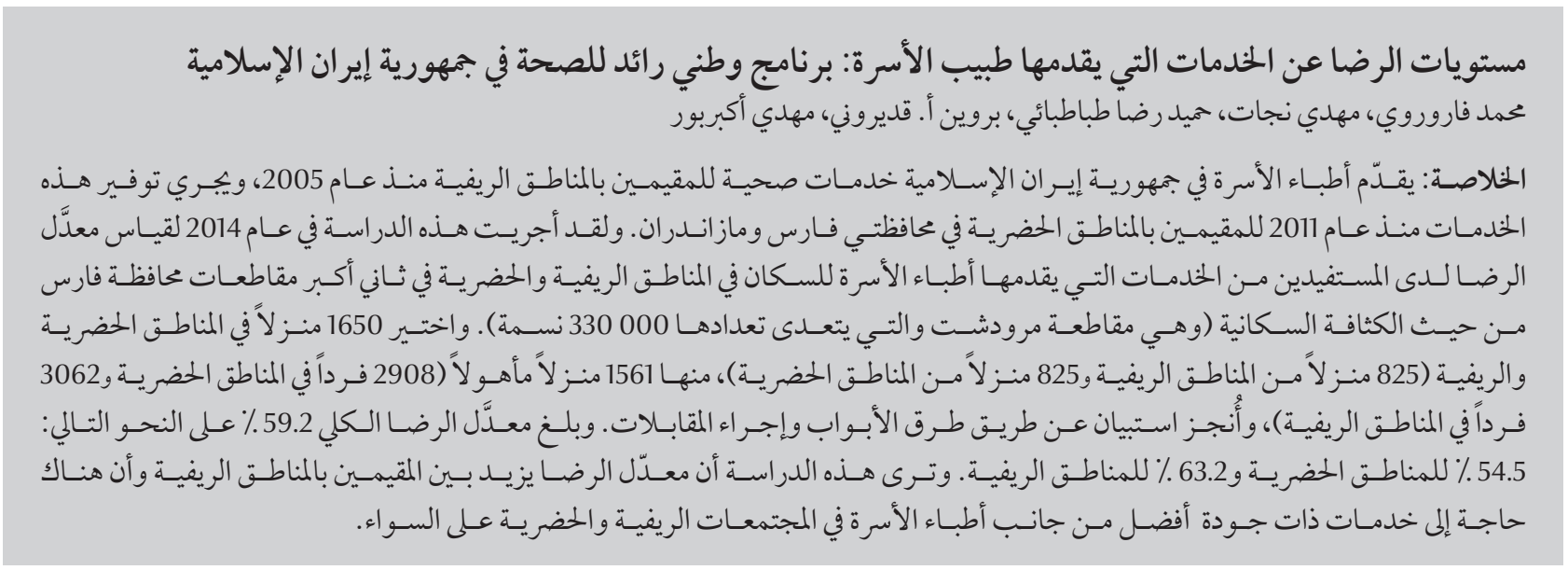

ABSTRACT Family physicians in the Islamic Republic of Iran have been providing health and medical services to residents from rural areas since 2005, and from 2011 these services have been delivered to urban residents in Fars and Mazandaran provinces. This study was conducted in 2014 to measure the rate of user satisfaction with services provided by family physicians to the rural and urban population of the second most populated county in Fars province (Marvdasht county, population > 330 000). In urban and rural areas, 1650 houses (825 in rural and 825 in urban areas) were selected, of which 1561 houses were inhabited (2908 individuals in urban and 3062 individuals in rural areas) and an interview-administered doorstep questionnaire was completed. Overall satisfaction rate was 59.2\%: 54.5\% for urban areas and 63.2\% for rural areas. This study suggests that satisfaction is higher among rural residents and that better quality services from family physicians are needed in both rural and urban communities.

Programme de santé pilote national en République islamique d'Iran : satisfaction concernant la prestation de services des médecins de famille

RÉSUMÉ En République islamique d'Iran, les médecins de famille fournissent des services médico-sanitaires aux habitants des zones rurales depuis 2005. Depuis 2011, les habitants urbains des provinces de Fars et Mazandaran bénéficient également de ces prestations de service. La présente étude a été menée en 2014 afin de mesurer le taux de satisfaction des bénéficiaires des services fournis par des médecins de famille aux populations urbaines et rurales du deuxième département le plus peuplé de la province de Fars, à savoir Marvdasht, qui regroupe une population de plus de 330000 habitants. Dans les zones urbaines et rurales, 1650 maisons (825 en zone rurale et 825 en zone urbaine) ont été sélectionnées, parmi lesquelles 1561 étaient habitées (2908 individus en zone urbaine et 3062 en zone rurale), et un questionnaire a été rempli sur la base d'entretiens " pas de porte.» Le taux de satisfaction global était de 59,2 \%, avec 54,5\% pour les zones urbaines et 63,2 \% pour les zones rurales. Cette étude suggère que la satisfaction est plus élevée parmi les habitants ruraux, et qu'il est nécessaire d'améliorer la qualité des services fournis par les médecins de famille dans les communautés rurales comme urbaines.

${ }^{7}$ HIV/AIDs Research Centre; ${ }^{2}$ Department of Health Affairs; ${ }^{3}$ Department of Epidemiology, School of Health; ${ }^{4}$ Department of Health Affairs, Shiraz University of Medical Sciences, Shiraz, Islamic Republic of Iran (Correspondence to: M. Fararouei:fararooei@gmail.com).

Received: 03/07/15; accepted: 19/10/16 


\section{Introduction}

Health is designated as a fundamental human right by almost all countries and its development is considered as one of the most important government responsibilities (1). Quality, accessible and cost-effective health services and satisfaction of users are the core principles in any health care system (2). Family physicians are used by national health systems in many countries to deliver basic medical care. The family physicians programme (FPP) seems to be an effective approach for increasing equitable access to health and medical services (3).

The fourth national strategic programme on Iran's economy and social and cultural development stresses the importance of expanding the coverage of health insurance, with a significant focus on the family physician and referral system. The Iranian FPP and patient referral system started in rural areas a long time ago (4). The FPP is running as a pilot project in urban areas of 2 provinces, Fars and Mazandaran. In Fars province, the fourth largest province by population, the urban family physician services have been delivered to urban residences since 2011 . A large number of staff and facilities are involved in this programme, in fact, about 1052 general practitioners, 1214 specialists, 376 laboratory centres, 134 radiology departments and 591 pharmacies are working with the Ministry of Health and Medical Education as a team member of the FPP ( $\underline{5})$.

According to the Iranian FPP and urban referral system guidelines, the participating family physicians are responsible for people's primary medical care and follow-up of patients whom they have referred to the specialized levels. Each urban residence can register with only 1 family physician, a general practitioner who participates in FPP and through whom required medical services are to be provided or arranged (1). As a result, the first line of contact of a person to the national health system is made via the family physician. As the first level of contact with the health system, family physicians provide some basic health and medical services, including primary health care, drug prescription and para-clinical services. If necessary, at the second and third levels, specialized out- or inpatient medical and para-medical services are delivered to patients referred by their family physician. After receiving services at the second and third levels, the results of diagnostic and therapeutic measures and other services are sent back to the family physician to be filed in the family's health file. All services which are provided by the FPP are free or subsidized by the government. Patients who do not want to use referral services or want to use medical services from the private sector are charged for all costs (4). In rural areas, health houses run by trained health staff are responsible for primary health and treatment care. In case of necessity or users' request, patients may be referred to the rural health centre to visit a family physician (4).

According to World Health Organization (WHO) guidelines, all countries need to establish continuous monitoring and evaluation programmes to evaluate the health system in order to increase effectiveness, quality of health services and user satisfaction (6). These monitoring programmes are to assess short- and long-term benefits, including improvements in health status and its related indexes, rate of accessibility, types and quality of care and user satisfaction, as well as the costs of the health services.

Among the above indices, measuring the level of user satisfaction is important as it directly and indirectly represents the efficacy and quality of health services. Rate of satisfaction with health services should be regarded as a fundamental measure for evaluation of any health programme (4). Evaluation studies, as suggested by WHO, are effective in identifying and solving problems of national health services
(6). Nevertheless, evaluation studies on Iranian user's satisfaction with services provided by family physicians are limited.

Marvdasht is one of the largest counties in Fars province, with a population of more than 330000,170000 urban and 160000 rural. The county has 1 city, Marvdasht, and more than 200 villages. Marvdasht is the second largest city after Shiraz, the capital of Fars province. According to the official report of the Ministry of Health of Fars province, in this county the public sector runs 1 hospital, 24 government health centres and 115 health houses. Medical and health services are also provided by the private sector via 310 nongovernmental clinics and medical centres (run by 63 specialists, 73 general practitioners and 39 dentists).

The aim of this study was to measure the satisfaction with medical services provided by family physicians in rural and urban areas of Marvdasht county.

\section{Methods}

This cross-sectional study was conducted in Marvdasht county, Fars province, in 2014. Sampling was done through a multi-stage cluster design. The household was defined as the sampling unit.

Prior to the main study, a pilot study on 160 households from the same source population was carried out to evaluate the questionnaire and sampling procedures. According to the results of the pilot study, although sample size was estimated at 2800 households (for rural and urban areas separately), due to the expectation of the presence of temporarily or permanently uninhabited houses in both, 1650 houses ( 825 in rural and 825 in urban areas) were selected, of which 1561 houses were habited (2908 individuals in urban and 3062 individuals in rural areas in total participated, of which 4312 households were registered with the FPP). Only 
27 households in rural and 62 in urban areas did not agree to participate.

Information was collected through completing a doorstep questionnaire via interview administered by trained health nurses. The content validity of the questionnaire was evaluated by an expert committee consisting of a family physician, a community medicine physician, a public health specialist and 2 epidemiologists. The questionnaire and all research procedures were evaluated and revised during the pilot study. The reliability of the questionnaire was evaluated using the test-retest approach (Cronbach alpha $=0.67)$. Household members over 18 years of age were interviewed by a same-sex interviewer. The mother (or homemaker) was also interviewed on behalf of underage household members or those who were not available for interview. The status of perceived satisfaction with the FPP and referral system was categorized in 5 levels: totally dissatisfied, dissatisfied, moderate, satisfied and totally satisfied. Information on the type of provider and quality of the most recent health services used by the participants (excluding dental health services) was obtained from the participants during the interview.

The service providers to the rural population are divided into 7 categories: health houses, rural health centres, family physician, private physician, government hospital, private hospital and other. The service providers to the urban population are divided in to 6 categories: urban health centre, family physician, private physician, government hospital, private hospital and other.

The main reason for selecting a particular service provider was elicited (asked as an open-ended question) from the participants. The answers were later combined into 3 categories: availability, costs and quality of provided services. The main reason (asked as an open-ended question) for dissatisfaction were combined into 4 categories: poor quality of the services, inappropriate behaviour of the staff, time consuming and high costs.

At first, satisfaction with FPP and referral systems was measured generally. In the next step, the satisfaction with the most recent medical service they used was measured. However, to respect the household's privacy and to increase the participation rate, no specific question was asked about their medical problems.

The study protocol was reviewed and approved by the research ethics committee of Shiraz University of Medical Sciences. Verbal informed consent was obtained before the interview was performed. Stratified cluster random sampling was used as the sampling method. The sampling procedures were carried out separately in rural and urban areas. However, the final sample sizes for rural and urban areas were representative of the corresponding rural/ urban population ratio in the study population.

The collected data and the level (and the reasons) of the user's satisfaction with provided services were analysed using SPSS, version19, and the chisquared test.

\section{Results}

The required information was collected from the final sample of participating families (763 urban and 798 rural). The registration rate with family physicians was about $83.9 \%$ in urban and $95.6 \%$ in rural areas $(P<0.001,89.9 \%$ for the whole county). The rate of never using FPP services among individuals registered with a family physician was relatively similar in rural and urban communities $(P=0.69)$. Overall, only $1.4 \%$ of participants registered with the FPP had never used the services (Table 1).

Among registered urban and rural families who used the FPP and referral system services, only $54.5 \%$ and $63.2 \%$ respectively reported being satisfied (totally satisfied or satisfied) $(P<0.001)$, with a total satisfaction rate of $59.2 \%$ (Table 2 ).

The rates of urban and rural service users' satisfaction with service providers are presented in Table 3 . The rate of satisfaction in both urban and rural users was higher among those who used medical services delivered by private providers compared with FPP service providers $(P<0.001)$. The lowest satisfaction rate was reported for services which were delivered by public health centres and family physicians.

For the most recent visit to a medical care provider, family physician services

\begin{tabular}{|c|c|c|c|c|c|c|c|c|c|}
\hline \multirow[t]{2}{*}{ Residence } & \multirow[t]{2}{*}{ No. } & \multicolumn{2}{|c|}{$\begin{array}{c}\text { Registered with } \\
\text { FPP }\end{array}$} & \multicolumn{2}{|c|}{$\begin{array}{c}\text { Not registered with } \\
\text { FPP }\end{array}$} & \multicolumn{2}{|c|}{$\begin{array}{l}\text { Registered and } \\
\text { used FPP servizces }\end{array}$} & \multicolumn{2}{|c|}{$\begin{array}{l}\text { Registered but not } \\
\text { used FPP services }\end{array}$} \\
\hline & & No. & $\%$ & No. & $\%$ & No. & $\%$ & No. & $\%$ \\
\hline Urban & 763 & 640 & 83.9 & 123 & 16.1 & 630 & 98.4 & 10 & 1.6 \\
\hline Rural & 798 & 763 & 95.6 & 35 & 4.4 & 753 & 98.7 & 10 & 1.3 \\
\hline \multirow[t]{2}{*}{ Total } & 1561 & 1403 & 89.9 & 158 & 10.1 & 1383 & 98.6 & 20 & 1.4 \\
\hline & & \multicolumn{4}{|c|}{$\chi^{2}=59.0, P<0.001$} & \multicolumn{4}{|c|}{$\chi^{2}=0.15, P=0.69$} \\
\hline
\end{tabular}




\begin{tabular}{|c|c|c|c|c|c|c|c|c|c|c|c|}
\hline \multirow[t]{2}{*}{ Residence } & \multirow[t]{2}{*}{ No. } & \multicolumn{2}{|c|}{$\begin{array}{c}\text { Totally } \\
\text { dissatisfied }\end{array}$} & \multicolumn{2}{|c|}{ Dissatisfied } & \multicolumn{2}{|c|}{ Moderate } & \multicolumn{2}{|c|}{ Satisfied } & \multicolumn{2}{|c|}{ Totally satisfied } \\
\hline & & No. & $\%$ & No. & $\%$ & No. & $\%$ & No. & $\%$ & No. & $\%$ \\
\hline Urban & 630 & 66 & 10.4 & 80 & 12.7 & 141 & 22.4 & 151 & 24.0 & 192 & 30.5 \\
\hline Rural & 753 & 39 & 5.2 & 64 & 8.5 & 174 & 23.1 & 242 & 32.1 & 234 & 31.1 \\
\hline \multirow[t]{2}{*}{ Total } & 1383 & 105 & 7.6 & 144 & 10.4 & 315 & 22.8 & 393 & 28.4 & 426 & 30.8 \\
\hline & \multicolumn{11}{|c|}{$\chi 2=26.6, P<0.001$} \\
\hline
\end{tabular}

were used by $43.5 \%$ of urban and $46.7 \%$ of rural individuals (overall 45.1\%). Moreover, only $4.3 \%$ of the participants in the rural areas visited health houses for their medical services. The selection of service provider by rural and urban residents was statistically significantly different, with a higher rate of usage of
FPP services in rural areas $(P<0.0001)$ (Table 4).

Among urban residents, the most common (self-reported) reason

\begin{tabular}{|c|c|c|c|c|c|c|c|c|c|c|c|}
\hline \multirow[t]{3}{*}{ Service provider } & \multirow[t]{2}{*}{ No. } & \multicolumn{2}{|c|}{$\begin{array}{c}\text { Totally } \\
\text { dissatisfied }\end{array}$} & \multicolumn{2}{|c|}{ Dissatisfied } & \multicolumn{2}{|c|}{ Moderate } & \multicolumn{2}{|c|}{ Satisfied } & \multicolumn{2}{|c|}{ Totally satisfied } \\
\hline & & No. & $\%$ & No. & $\%$ & No. & $\%$ & No. & $\%$ & No. & $\%$ \\
\hline & \multicolumn{11}{|c|}{ Urban } \\
\hline Health house* & NA & - & - & - & - & - & - & - & - & - & - \\
\hline Health centre* & 74 & 2 & 2.7 & 2 & 2.7 & 24 & 32.4 & 28 & 37.8 & 18 & 24.3 \\
\hline Family physician* & 956 & 40 & 4.2 & 88 & 9.2 & 230 & 24.1 & 241 & 25.2 & 357 & 37.3 \\
\hline Private physician & 681 & 33 & 4.8 & 22 & 3.2 & 134 & 19.7 & 214 & 31.4 & 278 & 40.8 \\
\hline Public hospital* & 429 & 14 & 3.3 & 21 & 4.9 & 80 & 18.6 & 157 & 36.6 & 157 & 36.6 \\
\hline Private hospital & 31 & 2 & 6.5 & 0 & 0.0 & 3 & 9.7 & 7 & 22.6 & 19 & 61.3 \\
\hline Other & 27 & 0 & 0.0 & 0 & 0.0 & 5 & 18.5 & 12 & 44.4 & 10 & 37.0 \\
\hline \multirow[t]{2}{*}{ Total } & 2198 & 91 & 4.1 & 133 & 6.1 & 476 & 21.7 & 659 & 30.0 & 839 & 38.2 \\
\hline & \multicolumn{11}{|c|}{ Rural } \\
\hline Health house* & 90 & 7 & 7.8 & 12 & 13.3 & 22 & 24.4 & 24 & 26.7 & 25 & 27.8 \\
\hline Health centre* & 93 & 4 & 4.3 & 7 & 7.5 & 12 & 12.9 & 21 & 22.6 & 49 & 52.7 \\
\hline Family physician* & 988 & 30 & 3.0 & 83 & 8.4 & 210 & 21.3 & 276 & 27.9 & 389 & 39.4 \\
\hline Private physician & 594 & 14 & 2.4 & 13 & 2.2 & 104 & 17.5 & 206 & 34.7 & 257 & 43.3 \\
\hline Public hospital* & 315 & 19 & 6.0 & 12 & 3.8 & 54 & 17.1 & 94 & 29.8 & 136 & 43.2 \\
\hline Private hospital & 22 & 2 & 9.1 & 0 & 0.0 & 1 & 4.5 & 4 & 18.2 & 15 & 68.2 \\
\hline Other & 12 & 2 & 16.7 & 2 & 16.7 & 0 & 0.0 & 6 & 50.0 & 2 & 16.7 \\
\hline \multirow[t]{2}{*}{ Total } & 2114 & 78 & 3.7 & 129 & 6.1 & 403 & 19.1 & 631 & 29.8 & 873 & 41.3 \\
\hline & \multicolumn{11}{|c|}{ Overall total } \\
\hline Health house* & 90 & 7 & 7.8 & 12 & 13.3 & 22 & 24.4 & 24 & 26.7 & 25 & 27.8 \\
\hline Health centre* & 167 & 6 & 3.6 & 9 & 5.4 & 36 & 21.6 & 49 & 29.3 & 67 & 40.1 \\
\hline Family physician* & 1944 & 70 & 3.6 & 171 & 8.8 & 440 & 22.6 & 517 & 26.6 & 746 & 38.4 \\
\hline Private physician & 1275 & 47 & 3.7 & 35 & 2.7 & 238 & 18.7 & 420 & 32.9 & 535 & 42.0 \\
\hline Public hospital* & 744 & 33 & 4.4 & 33 & 4.4 & 134 & 18.0 & 251 & 33.7 & 293 & 39.4 \\
\hline Private hospital & 53 & 4 & 7.5 & 0 & 0.0 & 4 & 7.5 & 11 & 20.8 & 34 & 64.2 \\
\hline Other & 39 & 2 & 5.1 & 2 & 5.1 & 5 & 12.8 & 18 & 46.2 & 12 & 30.8 \\
\hline Total & 4312 & 169 & 3.9 & 262 & 6.1 & 879 & 20.4 & 1290 & 29.9 & 1712 & 39.7 \\
\hline
\end{tabular}

*Under FPP services.

$N A=$ not available. 


\begin{tabular}{|c|c|c|c|c|c|c|c|c|c|c|c|c|c|c|c|}
\hline \multirow[t]{2}{*}{ Residence } & \multirow[t]{2}{*}{$\begin{array}{c}\text { Total } \\
\text { No. }\end{array}$} & \multicolumn{2}{|c|}{ Health house } & \multicolumn{2}{|c|}{$\begin{array}{l}\text { Health } \\
\text { centre }\end{array}$} & \multicolumn{2}{|c|}{$\begin{array}{l}\text { Family } \\
\text { physician }\end{array}$} & \multicolumn{2}{|c|}{$\begin{array}{l}\text { Private } \\
\text { physician }\end{array}$} & \multicolumn{2}{|c|}{$\begin{array}{c}\text { Public } \\
\text { hospital }\end{array}$} & \multicolumn{2}{|c|}{$\begin{array}{l}\text { Private } \\
\text { hospital }\end{array}$} & \multicolumn{2}{|c|}{ Other } \\
\hline & & No. & $\%$ & No. & $\%$ & No. & $\%$ & No. & $\%$ & No. & $\%$ & No. & $\%$ & No. & $\%$ \\
\hline Urban & 2204 & NA & - & 74 & 3.4 & 958 & 43.5 & 681 & 30.9 & 433 & 19.6 & 31 & 1.4 & 27 & 1.2 \\
\hline Rural & 2117 & 90 & 4.3 & 93 & 4.4 & 989 & 46.7 & 595 & 28.1 & 316 & 14.9 & 22 & 1.0 & 12 & 0.6 \\
\hline Total & 4321 & 90 & 2.1 & 167 & 3.9 & 1947 & 45.1 & 1276 & 29.5 & 749 & 17.3 & 53 & 1.2 & 39 & 0.9 \\
\hline
\end{tabular}

$N A=$ not available.

(62.6\%) for selection of FPP provided services was low cost. The most common reason for selecting private services was quality of service (84.9\%). In rural areas, availability was the most common reason for using FPP services (47.8\%); again, quality of service was the most common reason for using private provider services $(89.7 \%)$. We found statistically significant differences between rural and urban residents in the reasons given for choosing a medical services provider $(P<0.0001)$ (Table 5).

The most common reasons for dissatisfaction with services provided by family physicians among urban residents were the quality of services (79.4\%) and inappropriate behaviour (14.3\%). The situation was similar for rural areas: dissatisfaction with the quality of services provided (68.7\%) and inappropriate behaviour (20.7\%) (Table 6).

\begin{tabular}{|c|c|c|c|c|c|c|c|}
\hline \multirow[t]{2}{*}{ Service provider } & \multirow[t]{2}{*}{ No. service users } & \multicolumn{2}{|c|}{ Availability } & \multicolumn{2}{|c|}{ Cost } & \multicolumn{2}{|c|}{ Quality } \\
\hline & & No. & $\%$ & No. & $\%$ & No. & $\%$ \\
\hline & \multicolumn{7}{|c|}{ Urban } \\
\hline Health house & NA & - & - & - & - & - & - \\
\hline Health centre & 74 & 30 & 40.5 & 24 & 32.4 & 20 & 27.0 \\
\hline Family physician & 956 & 223 & 23.3 & 598 & 62.6 & 135 & 14.1 \\
\hline Private physician & 681 & 78 & 11.5 & 25 & 3.7 & 578 & 84.9 \\
\hline Government hospital & 433 & 91 & 21.0 & 163 & 37.6 & 179 & 41.3 \\
\hline Private hospital & 31 & 0 & 0.0 & 0 & 0.0 & 31 & 100.0 \\
\hline Other & 27 & 10 & 37.0 & 7 & 25.9 & 10 & 37.0 \\
\hline \multirow[t]{2}{*}{ Total } & 2202 & 432 & 19.6 & 817 & 37.1 & 953 & 43.3 \\
\hline & \multicolumn{7}{|c|}{ Rural } \\
\hline Health house & 90 & 78 & 86.7 & 7 & 7.8 & 5 & 5.6 \\
\hline Health centre & 93 & 53 & 57.0 & 24 & 25.8 & 16 & 17.2 \\
\hline Family physician & 988 & 472 & 47.8 & 315 & 31.9 & 201 & 20.3 \\
\hline Private physician & 595 & 50 & 8.4 & 11 & 1.8 & 534 & 89.7 \\
\hline Government hospital & 316 & 30 & 9.5 & 67 & 21.2 & 219 & 69.3 \\
\hline Private hospital & 22 & 0 & 0.0 & 0 & 0.0 & 22 & 100.0 \\
\hline Other & 12 & 3 & 25.0 & 3 & 25.0 & 6 & 50.0 \\
\hline \multirow[t]{2}{*}{ Total } & 2116 & 686 & 32.4 & 427 & 20.2 & 1003 & 47.4 \\
\hline & \multicolumn{7}{|c|}{ Overall total } \\
\hline Health house & 90 & 78 & 86.7 & 7 & 7.8 & 5 & 5.6 \\
\hline Health centre & 167 & 83 & 49.7 & 48 & 28.7 & 36 & 21.6 \\
\hline Family physician & 1944 & 695 & 35.8 & 913 & 47.0 & 336 & 17.3 \\
\hline Private physician & 1276 & 128 & 10.0 & 36 & 2.8 & 1112 & 87.1 \\
\hline Government hospital & 749 & 121 & 16.2 & 230 & 30.7 & 398 & 53.1 \\
\hline Private hospital & 53 & 0 & 0.0 & 0 & 0.0 & 53 & 100.0 \\
\hline Other & 39 & 13 & 33.3 & 10 & 25.6 & 16 & 41.0 \\
\hline Total & 4318 & 1118 & 25.9 & 1244 & 28.8 & 1956 & 45.3 \\
\hline
\end{tabular}

$N A=$ not available 


\begin{tabular}{|c|c|c|c|c|c|c|c|c|c|}
\hline \multirow[t]{2}{*}{ Service provider } & \multirow[t]{2}{*}{ No. dissatisfied } & \multicolumn{2}{|c|}{ Poor quality } & \multicolumn{2}{|c|}{$\begin{array}{l}\text { Inappropriate } \\
\text { behaviour }\end{array}$} & \multicolumn{2}{|c|}{ Time consuming } & \multicolumn{2}{|r|}{ Cost } \\
\hline & & No. & $\%$ & No. & $\%$ & No. & $\%$ & No. & $\%$ \\
\hline & \multicolumn{9}{|c|}{ Urban } \\
\hline Health house & NA & - & - & - & & - & - & - & - \\
\hline Health centre & 6 & 5 & 83.3 & 1 & 16.7 & 0 & 0.0 & 0 & 0.0 \\
\hline Family physician & 175 & 139 & 79.4 & 25 & 14.3 & 11 & 6.3 & 0 & 0.0 \\
\hline Private physician & 117 & 60 & 51.3 & 13 & 11.1 & 14 & 12.0 & 30 & 25.6 \\
\hline Government hospital & 48 & 22 & 45.8 & 6 & 12.5 & 20 & 41.7 & 0 & 0.0 \\
\hline Private hospital & 5 & 0 & 0.0 & 2 & 40.0 & 0 & 0.0 & 3 & 60.0 \\
\hline Other & 0 & 0 & 0.0 & 0 & 0.0 & 0 & 0.0 & 0 & 0.0 \\
\hline \multirow[t]{2}{*}{ Total } & 351 & 226 & 64.4 & 47 & 13.4 & 45 & 12.8 & 33 & 9.4 \\
\hline & \multicolumn{9}{|c|}{ Rural } \\
\hline Health house & 30 & 26 & 86.7 & 1 & 3.3 & 3 & 10.0 & 0 & 0.0 \\
\hline Health centre & 14 & 14 & 100.0 & 0 & 0.0 & 0 & 0.0 & 0 & 0.0 \\
\hline Family physician & 179 & 123 & 68.7 & 37 & 20.7 & 19 & 10.6 & 0 & 0.0 \\
\hline Private physician & 67 & 20 & 29.9 & 7 & 10.4 & 18 & 26.9 & 22 & 32.8 \\
\hline Government hospital & 40 & 11 & 27.5 & 2 & 5.0 & 27 & 67.5 & 0 & 0.0 \\
\hline Private hospital & 3 & 0 & 0.0 & 0 & 0.0 & 2 & 66.7 & 1 & 33.3 \\
\hline Other & 4 & 4 & 100.0 & 0 & 0.0 & 0 & 0.0 & 0 & 0.0 \\
\hline \multirow[t]{2}{*}{ Total } & 337 & 198 & 58.8 & 47 & 13.9 & 69 & 20.5 & 23 & 6.8 \\
\hline & \multicolumn{9}{|c|}{ Overall total } \\
\hline Health house & 30 & 26 & 86.7 & 1 & 3.3 & 3 & 10.0 & 0 & 0.0 \\
\hline Health centre & 20 & 19 & 95.0 & 1 & 5.0 & 0 & 0.0 & 0 & 0.0 \\
\hline Family physician & 354 & 262 & 74.0 & 62 & 17.5 & 30 & 8.5 & 0 & 0.0 \\
\hline Private physician & 184 & 80 & 43.5 & 20 & 10.9 & 32 & 17.4 & 52 & 28.3 \\
\hline Government hospital & 88 & 33 & 37.5 & 8 & 9.1 & 47 & 53.4 & 0 & 0.0 \\
\hline Private hospital & 8 & 0 & 0.0 & 2 & 25.0 & 2 & 25.0 & 4 & 50.0 \\
\hline Other & 4 & 4 & 100.0 & 0 & 0.0 & 0 & 0.0 & 0 & 0.0 \\
\hline Total & 688 & 424 & 61.6 & 94 & 13.7 & 114 & 16.6 & 56 & 8.1 \\
\hline
\end{tabular}

$N A=$ not available .

\section{Discussion}

We found that approximately 3 years after applying the urban FPP, more than $80 \%$ of urban families and $95.6 \%$ of rural families had registered. The difference could be due to the more limited service providers or better access to family physicians in rural areas. However, the satisfaction rates for medical services are quite low depending on the residence of the study population. Our findings are more or less supported by several other studies. In a study done in rural areas of Shahr-e-Kord, the rate of satisfaction with family physicians in the rural area was about 50\% (7). However, in another study on an insured population in Sabzevar. the rate of satisfaction with physicians in small cities $(<20000$ population) and villages was significantly higher, $85.7 \%$ (8). Satisfaction rates of $70.3 \%$ and $51.3 \%$ have been reported among the rural population in other parts of the country $(9,10)$.

We found the rate of dissatisfaction among urban residents was 1.5 times higher than among rural residents. This could be related to greater expectations and lack of direct access to their preferred physicians. Considering the different types of medical service providers, our findings suggest that use of the family physician's services was high in both urban and rural areas; the main reasons for using these FPP services were lower costs and accessibility. Among urban and rural families, the most common reason for dissatisfaction with FPP services was lack of variation and quality of the services and inappropriate behaviour of staff, especially the physicians. Based on the results, it seems that providing more services with better quality could help in improving user's satisfaction with FPP programme.

The Iranian Ministry of Health and |Medical Education has been running FPP for fewyears with great expenditure. 
It is necessary to conduct periodic evaluation studies on the effectiveness and cost benefit of FPP. Currently, dissatisfaction with FPP seems high and significant improvement in the quality and quantity of the services is crucial.

Our study had some limitations. The items in the questionnaire measured the respondents' perception on the subjects. The answers to openended questions were later reviewed and combined by two members of the research team.

\section{Acknowledgement}

The present study is a part of the MSc thesis (Satisfaction with services provided by family physicians in rural and urban areas of Marvdasht county) by Mehdi Nejat under the supervision of Dr Mohamad Fararouie.

Funding: The study was financially supported by Shiraz University of Medical Sciences.

Competing interests: None declared.

\section{References}

1. Instruction of family physician and referral system in urban areas. Tehran: Ministry of Health and Medical Education; 2012:96 [in Farsi].

2. Davoudi S. An introduction to health sector reform. Tehran: Asare Mouaser; 2006:247 [in Farsi]

3. Family physicians: what you should know about family physicians. Tehran: Ministry of Health and Medical Education, Department of Health; 2012.

4. Executive instruction of family physician and rural insurance. Tehran: Ministry of Health and Medical Education; 2014:217 [in Farsi].

5. Introduction to Marvdasht health network. Shiraz: Shiraz University of Medical sciences; 2016 (http://marve.sums.ac.ir/ shabakeh/moarefishabake.html, accessed 28 February 2017) [in Farsi].

6. Monitoring and evaluation of health systems strengthening. An operational framework. Geneva: World Health Organization; 2009.
7. Alidoosti M, Tavassoli E, Delaram M, Najimi A, Sharifirad G. The relationship between satisfaction and knowledge about family-doctor program in Shahr-e-Kord. Zahedan J Res Med Sci. 2011;13(6):36-9.

8. Ghorbani A, Shegarf Nakhaie M, Dovlat Abadi A, Alemi H, Tabarraie Y. Study of satisfaction rate of family medicine plan in insured population of Sabzevar University of Medical Sciences. J Sabzevar University Med Sci. 2012;19(4):364-70.

9. Khadivi R, Golshiri P, Farasat E, Khaledi G. Caregiver satisfaction in rural areas in Isfahan district, Iran, after implementation of the family physician project. J Isfahan Med Sch. 2013;31(244):1048-58.

10. NasrollahPur Shirvsni D, Ashrafian H, Motlagh M, Kabir M, Tourani S, Sabestani MounfaredA, et al. Satisfaction of service recipients from health center with family physician program in northern provinces of Iran:2008. J Nursing \& Midwifery Faculty, Rafsenjan University of Medical Sciences and Health Services. 2009;3(4):1-10. 